Jurnal SPORTIF: Jurnal Penelitian Pembelajaran

Vol. 6 No. 2, Agustus 2020, pp. 390-406

doi) https://doi.org/10.29407/js_unpgri.v6i2.13765

\title{
Faktor kemampuan fisik dan psikologis penunjang keterampilan atlet elit sepakbola Propinsi Papua
}

\section{Physical and psychological ability factors supporting the skills of Papua football elite athletes}

\author{
Tri Setyo Guntoro', Junalia Muhammad², and Rif'iy Qomarrullah ${ }^{3}$ \\ 1,2,3 Department of Sports Science, Universitas Cenderawasih, Jl. Kamp Wolker Waena, \\ Jayapura, Papua Province, 99351, Indonesia
}

Received: 14 October 2019; Revised: 20 June 2020; Accepted: 18 July 2020

\begin{abstract}
Abstrak
Tujuan utama dari riset yang telah dilakukan yakni analisis faktor kemampuan fisik serta psikologis dengan prestasi pada atlet sepakbola usia 16-21 tahun. Pendekatan yang dilakukan dalam penelitian ini adalah pendekatan kuantitatif, menggunakan desain analisis faktor konfirmatori dengan metode satistik multivariat yang mengukur variabel dominan kemampuan fisik dan psikologis dalam keterampilan sepakbola. Subyek dalam penelitian ini berjumlah 34 orang atlet sepakbola Papua Indonesia, dilaksanakan pada Agustus 2019 menggunakan purposive sampling. Instrumen yang digunakan dalam penelitian ini yakni: (1) pengukuran anatomi tubuh; (2) tes kemampuan biomotor; (3) pengukuran psikologis; (4) tes teknik keterampilan sepakbola. Adapun hasil dari penelitian ini yakni: (1) faktor kecepatan lari memberikan dampak signifikan bagi keterampilan teknik dengan nilai kontribusi 0,702, dan (2) faktor daya tahan tubuh memberikan tidak memberikan dampak signifikan untuk keterampilan teknik dengan nilai kontribusi 0,248 . Kemudian kesimpulan dari penelitian ini yaitu bahwa faktor yang paling dominan memberikan pengaruh pada keterampilan permainan sepakbola adalah kecepatan, sedangkan yang terendah daya tahan. Hasil riset yang telah dilaksanakan memberikan gambaran kepada pelatih/atlet, peneliti, dan pemangku kepentingan untuk dapat menggunakan hasil penelitian ini sebagai rujukan, karena memberikan kontribusi dalam pembinaan olahraga prestasi. Namun, keterbatasan dari penelitian ini adalah baru dilaksanakan pada olahraga sepakbola di Papua dan terbatas pada atlet PON (Pekan Olahraga Nasional), sehingga dibutuhkan penelitian lanjutan yang lebih luas cakupannya.
\end{abstract}

Kata kunci: analisis faktor, sepakbola, Papua.

\begin{abstract}
The main objective of this study was to analyze the physical and psychological ability factors that affect the achievement of football athletes between the ages of 16-21 years. The approach taken in this study was quantitative, using a confirmatory factor analysis design with multivariate statistical methods. This approach measures the dominant variables of physical and psychological abilities in football skills. The subjects used in this study were 34 Papua football athletes who were selected using the purposive sampling conducted in August 2019. The instruments used were body anatomy measurement, biomotor ability test, psychological measurement, and football skill technical test. The results of this study showed that running speed factor had a significant impact on technical
\end{abstract}

Correspondence author: Rifqy Qomarrullah, Universitas Cenderawasih, Indonesia.

Email: qomarrifqi77@gmail.com 
skills with a contribution value of 0.702 . Furthermore, it showed that endurance factor with a contribution value of 0.248 did not have a significant impact on technical skills. Therefore, it was concluded that the most dominant factor influencing the Papua football team skills was speed, while the lowest was endurance. This study was beneficial to trainers/athletes, researchers, and stakeholders because its results were used as references in achieving sports coaching. However, the limitation of this study was that it has only been carried out in the football sport in Papua and is limited to PON (National Sports Week) athletes. Therefore, further studies are needed with a wider scope.

Keywords: factor analysis, football, Papua.

\section{PENDAHULUAN}

Cabang olahraga (cabor) sepakbola merupakan olahraga permainan yang dilakukan secara beregu dan sangat digemari oleh masyarakat di Indonesia (Widodo, 2018). Sepakbola modern menuntut pemain untuk memiliki performa unggul tidak hanya dari aspek fisik (Kurniawan, dkk, 2016). Adapun aspek lain yang menunjang dalam prestasi sepakbola yakni: faktor teknik, taktik, mental, dan biomotor (fisik) (Kusuma, 2018). Olahraga sepakbola menjadi salah satu cabor yang dipertandingkan dalam PON (Pekan Olahraga Nasional) ke-20 di Propinsi Papua. Oleh karenanya, cabor sepakbola Propinsi Papua berupaya menjaga eksistensinya di dunia olahraga tanah air. Olahraga sepakbola merupakan olahraga dengan syarat gengsi, oleh karenanya target medali emas merupakan kebanggaan tersendiri bagi kontingen Propinsi Papua dalam perhelatan akbar yang akan digelar pada tahun 2020. Berdasarkan catatan penulis sebagai pengurus KONI (Komite Olahraga Nasional Indonesia) Provinsi Papua tahun 2019, PON XX tahun 2020 rencananya diikuti oleh kontingen dari 33 Provinsi dari seluruh Indonesia, melibatkan 15.000 orang (wasit/juri, atlet, pelatih, official), yang terbagi dalam 36 cabor dan lebih dari 60-an disiplin dan 756-an event.

Berdasarkan studi pendahuluan awal tahun 2019 yang diperoleh dari data KONI Propinsi Papua dan tim pelatih sepakbola PON Propinsi Papua tahun 2018 s/d 2019, beberapa kendala saat ini masih dihadapi sekuat tim sepakbola Papua bahwa faktor kelelahan kondisi fisik yang tidak prima masih menjadi momok bagi tim sepakbola junior dan senior. Kemudian, kemampuan teknik dasar pemain pada usia junior terjadi 
kesenjangan ketika memasuki usia senior salah satunya adalah lemahnya dukungan ilmu pengetahuan dan teknologi keolahragaan (IPTEKOR). Adanya permasalahan sosial yakni perkelahian pemain dan etika pemain terutama kedisiplinan latihan serta pola hidup masih menjadi salah satu persoalan aspek mental bagi pembinaan olahraga prestasi di Propinsi Papua.

Penelitian ini menjadi penting untuk dilakukan karena selaras dengan esensi pembinaan dan pencapaian prestasi olahraga. Morgan \& Batlle (2019) untuk mendapatkan hasil yang maksimal, maka harus dilaksanakan dengan konsisten, berjenjang, mendasar, sistematis, efisien, dan terpadu. Adapun beberapa riset terdahulu yang penting sebagai penguat kajian dalam penelitian ini, antara lain seperti penelitian Trecroci, dkk. (2018) dimana selama uji kemampuan fisik atlet elit dan sub-elit usia 15 tahun di Kota Milan Italia, terdapat perbedaan yang siginifikan pada kemampuan sprint, namun untuk kelincahan relatif tidak ada perbedaan yang menonjol. Selanjutnya, Hatzigeorgiadis, dkk (2014) menemukan jika kata-kata bijak yang memberikan semangat dan inspiratif dari pelatih mampu memberikan penguatan mental emosional, dan meningkatkan kontribusi positif terhadap performa atlet saat menghadapi kompetisi. Sedangkan, Hidayat, dkk (2019) menyimpulkan bahwa kebutuhan fisik bagi pemain sepakbola berbeda, data menunjukkan bahwa untuk latihan daya tahan otot $55,00 \%$, kecepatan $14,00 \%$, power $14,00 \%$, kelincahan $14,00 \%$, kekuatan tungkai $1,15 \%$, kekuatan otot perut $1,50 \%$.

Hasil penelitian yang dilaksanakan memiliki arti penting bagi prestasi dan kemajuan dunia olahraga di Propinsi Papua karena penelitian ini berfokus pada olahraga permainan yang menjadi harga diri masyarakat Propinsi Papua. Kemudian, penelitian ini menjadi sangat penting karena dapat mengukur porsi fisik, teknik, dan mental untuk merumuskan program latihan yang tepat untuk menuju target medali emas.

Berdasarkan penelitian-penelitian tersebut, terdapat penguatan satu dengan yang lainnya namun dilakukan secara parsial dan baru dilaksanakan dengan metode kajian non-analisis faktor. Analisis faktor 
dalam penelitan ini merupakan implementasi metode statistik multivariat yang menerangkan hubungan antara sejumlah perubahan-perubahan yang saling independen antara satu dengan yang lain sehingga bisa dibuat satu atau lebih kumpulan perubahan yang lebih sedikit dari jumlah perubahan awal. Analisis statistik yang digunakan bertujuan untuk mengetahui faktor-faktor dominan kemampuan fisik dan psikologis dalam menjelaskan variabel yang paling berpengaruh terhadap keterampilan atlet sepakbola Propinsi Papua. Berdasarkan penelitian tersebut, kemudian dapat diberikan simpulan faktor dominan kemampuan fisik dan psikologis yang berpengaruh terhadap keterampilan khususnya dalam cabang olahraga sepakbola.

Oleh karenanya, hasil penelitian yang dilaksanakan memiliki arti penting bagi prestasi dan kemajuan dunia olahraga di Propinsi Papua karena penelitian ini berfokus pada olahraga permainan yang menjadi harga diri masyarakat Propinsi Papua, sebab dapat mengukur proporsi kemampuan fisik, teknik, dan psikologis untuk merumuskan program latihan yang tepat untuk menuju target medali emas. Kemudian penelitian ini dapat menjadi sumbangan keilmuan bagi atlet, dan pelatih sepakbola dalam menentukan formulasi program latihan yang tepat dan efektif.

\section{METODE}

Penelitian ini merupakan penelitian korelasional dengan pendekatan kuantitatif, dan menggunakan desain penelitian analisis faktor konfirmatori. Orcan (2018) penelitian ini mengidentifikasi korelasi antar indikator variabel dengan variabel utama (laten) dalam keterampilan teknik sepakbola. Populasi dan sampel dalam riset ini melibatkan pemain tim sepakbola Propinsi Papua yang sebanyak 34 orang dan berjenis kelamin laki-laki dengan teknik purposive sampling (Etikan, Musa, \& Alkassim, 2016), dan dilaksanakan pada bulan Agustus 2019. Adapun instrumen yang di gunakan dalam riset yang telah dilaksanakan yakni:

1. Pengukuran anatomi tubuh yakni: tes antropometri tinggi badan dan berat badan (Dewi \& Prihatanta, 2015).

2. Tes kemampuan biomotor meliputi: 
a. Kecepatan lari menggunakan tes lari $20 \mathrm{~m}$ pada garis lurus dengan waktu secepat-cepatnya dan diukur menggunakan detik (Indrayana \& Sukendro, 2019).

b. Fleksibilitas penggung menggunakan tes sit and reach diukur dalam centimeter $(\mathrm{cm})$ (Kurniawan, Kesoema, \& Hendrianingtyas, 2019).

c. Kekuatan power otot tungkai menggunakan tes leg strength memaikai alat leg dynamometer (Meliala, E. K. B. \& Fithroni, 2018).

d. Daya tahan aerobik, yakni kemampuan $\mathrm{VO}_{2} \mathrm{Max}$ diukur menggunakan tes multistage fitness test (MFT) (Asier \& Javier, 2018).

e. Koordinasi tes mata-kaki menggunakan (SWVT) soccer wall voley test (Rachman \& Nasution, 2017).

3. Pengukuran psikologis yakni pengukuran mental dan kepribadian olahraga diukur menggunakan butir-butir angket berdasarkan skala likert (Elemiri \& Aly, 2014).

4. Tes teknik keterampilan sepakbola yakni pengukuran unjuk kerja, yakni: tes memainkan bola dengan kepala (heading), tes passing dan stopping bola, tes menggiring bola (dribbling), tes menendang bola kegawang (shooting) (Mitrotasios, Souglis, Gioldasis, Kesaris, \& Kampouris, 2018).

Kemudian seluruh data yang telah dikumpulkan kemudian dianalisis faktor-faktornya (Amerieska \& Nurhidayah, 2014). Analisis statistik digunakan faktor-faktor untuk mengkaji keterkaitan dampak yang dari semua pengaruh yang ditimbulkan dari setiap variabel (Saptono, 2017).

\section{HASIL}

Hasil riset yang telah dilaksanakan memberikan beberapa temuan penting yaitu:

\section{Uji Prasyarat Analisis}

Berdasarkan hasil penelitian diperoleh data bahwa: 
Tabel 1. Impak Normalitas Tes

\begin{tabular}{|c|c|c|c|c|c|c|}
\hline Variabel-variabel & Min & Maks & Skew & C.R. & Kurtosis & C.R. \\
\hline Faktor psikologis (X9) & 59,000 & 108,000 & 0,245 & 0,479 & $-0,884$ & $-0,866$ \\
\hline Kelincahan (X8) & 44,000 & 51,000 & 0,989 & 1,936 & 1,359 & 1,331 \\
\hline Daya ledak (X7) & 31,000 & 93,000 & 0,185 & 0,362 & $-0,677$ & $-0,662$ \\
\hline Koordinasi (X6) & 37,000 & 69,000 & 0,413 & 0,809 & $-0,198$ & $-0,194$ \\
\hline Daya tahan (X5) & 16,000 & 65,000 & $-0,575$ & $-1,126$ & $-0,138$ & $-0,135$ \\
\hline Kecepatan (X4) & 24,000 & 79,000 & $-0,044$ & $-0,086$ & $-0,084$ & $-0,082$ \\
\hline Fleksibilitas (X3) & 8,000 & 68,000 & $-0,109$ & $-0,213$ & $-0,809$ & $-0,792$ \\
\hline Kekuatan (X2) & 32,000 & 71,000 & 0,035 & 0,069 & 0,122 & 0,119 \\
\hline Antropometri (X1) & 27,000 & 72,000 & $-0,075$ & $-0,147$ & $-0,530$ & $-0,519$ \\
\hline $\begin{array}{l}\text { Keterampilan teknik } \\
\text { (Y) }\end{array}$ & 206,000 & 372,000 & 0,313 & 0,614 & $-0,579$ & $-0,567$ \\
\hline Multivariate & & & & & 4,014 & 0,569 \\
\hline
\end{tabular}

Berdasarkan data impak normalitas tes diketahui bahwa seluruh variabel termasuk berkategori normal yakni 0,569 berdasarkan data gabungan maupun data secara parsial.

\section{Analisa Kesamaan Pola (Goodness-of-Fit) Apnea Jarak}

Berdasarkan analisis goodness of fit index (GFI) yang berasal dari bentuk riset penelitian seperti terlihat dalam tabel di bawah ini:

Tabel 2. Data GFI Pola Apnea

\begin{tabular}{lccc}
\hline \multicolumn{1}{c}{ Indeks GFI } & $\begin{array}{c}\text { Norma yang } \\
\text { dibutuhkan }\end{array}$ & Impak & Ulasan Pola \\
\hline \multicolumn{1}{c}{$\chi^{2}$} & Intensi rendah & 43,461 & Jelek \\
\hline Significance Probability & $\geq, 054$ &, 000 & Jelek \\
\hline $\begin{array}{l}\text { Normed Chi Square /Degree } \\
\text { of Freedom }\end{array}$ & $\leq 2,001$ & 2,897 & Teratur \\
\hline Goodness of fit index & $\geq, 92$ &, 699 & Jelek \\
\hline $\begin{array}{l}\text { Adjusted Goodness Fit of } \\
\text { Index }\end{array}$ & $\geq, 91$ &, 439 & Jelek \\
\hline Tucker Lewis Index & $\geq, 90$ &, 443 & Minor \\
\hline Comparative Fit Index & $\geq, 93$ &, 601 & Minor \\
\hline $\begin{array}{l}\text { The Root Mean Square } \\
\text { Error of Approximation }\end{array}$ & $\leq, 081$ &, 281 & Jelek \\
\hline
\end{tabular}

Berdasarkan semua penilaian tabel 2 mengisyaratkan jika pola didalam riset yang telah dilaksanakan tidak bisa diintegrasikan bersama impak probability dimana belum mencapai standar yang dipersyaratkan. Adapun pola riset yang ditawarkan belum bisa memenuhi kaidah, oleh sebab itu penulis melakukan sedikit perbaikan atau modifikasi agar tercapai standar sesuai dengan GFI. 
Tabel 3. Impak GFI Sesudah Konversi Pola Apnea Jarak

\begin{tabular}{lcccc}
\hline \multicolumn{1}{c}{ Indeks GFI } & $\begin{array}{c}\text { Impak yang } \\
\text { dibutuhkan }\end{array}$ & $\begin{array}{c}\text { Impak } \\
\text { Sebelum } \\
\text { Konversi }\end{array}$ & $\begin{array}{c}\text { Impak } \\
\text { Setelah } \\
\text { Konversi }\end{array}$ & $\begin{array}{c}\text { Ulasan } \\
\text { Pola }\end{array}$ \\
\hline$\chi^{2}$ & Intensi rendah & 43,461 & 13,245 & Teratur \\
\hline Significance Probability & $\geq, 05$ &, 000 & 0,351 & Teratur \\
\hline $\begin{array}{l}\text { Normed Chi Square } \\
\text { /Degree of Freedom }\end{array}$ & $\leq 2,00$ & 2,897 & 1,104 & Teratur \\
\hline Goodness of fit index & $\geq, 90$ & 0,699 & 0,90 & Teratur \\
\hline $\begin{array}{l}\text { Adjusted Goodness Fit of } \\
\text { Index }\end{array}$ & $\geq, 90$ &, 439 &, 904 & Teratur \\
\hline $\begin{array}{l}\text { Tucker Lewis Index } \\
\text { Comparative Fit Index }\end{array}$ & $\geq, 90$ &, 443 &, 970 & Teratur \\
\hline $\begin{array}{l}\text { The Root Mean Square } \\
\text { Error of Approximation }\end{array}$ & $\leq, 08$ &, 602 &, 983 & Teratur \\
\hline
\end{tabular}

Berdasarkan keseluruhan pengukuran goodness of fit (GFI) dimana pola yang dilakukan transformasi menunjukkan impak perubahan dan berarti riset yang dilaksanakan bisa diterima serta seuai dengan persyaratan GFI.

Tabel 4. Impak GFI Sesudah Transformasi Pola Apnea Waktu

\begin{tabular}{lcccc}
\hline \multicolumn{1}{c}{ Indeks GFI } & $\begin{array}{c}\text { Impak yang } \\
\text { dibutuhkan }\end{array}$ & $\begin{array}{c}\text { Impak } \\
\text { Sebelum } \\
\text { Konversi }\end{array}$ & $\begin{array}{c}\text { Impak } \\
\text { Setelah } \\
\text { Konversi }\end{array}$ & $\begin{array}{c}\text { Ulasan } \\
\text { Pola }\end{array}$ \\
\hline Significance Probability & Intensi rendah & 43,461 & 6,240 & Teratur \\
\hline $\begin{array}{l}\text { Normed Chi Square } \\
\text { /Degree of Freedom }\end{array}$ & $\geq, 05$ &, 000 &, 857 & Teratur \\
\hline Goodness of fit index & $\leq 2,00$ & 2,897 &, 567 & Teratur \\
\hline $\begin{array}{l}\text { Adjusted Goodness Fit of } \\
\text { Index }\end{array}$ & $\geq, 90$ &, 699 &, 930 & Teratur \\
\hline Tucker Lewis Index & $\geq, 90$ &, 439 &, 922 & Teratur \\
\hline Comparative Fit Index & $\geq, 90$ &, 460 & 1,123 & Teratur \\
\hline $\begin{array}{l}\text { The Root Mean Square } \\
\text { Error of Approximation }\end{array}$ & $\geq, 90$ &, 615 & 1,000 & Teratur \\
\hline \multicolumn{1}{c}{ Significance Probability } & $\leq, 08$ &, 281 &, 000 & Teratur \\
\hline
\end{tabular}

Berdasarkan keseluruhan pengukuran goodness of fit (GFI) sesudah dilakukan teransformasi pola seperti tertera dalam Tabel 4. menunjukkan jika riset ini bisa diterima serta memenuhi kaidah pola standar yang dibutuhkan.

\section{Eksperimentasi Hipotesa}

Eksperimentasi hipotesa dianalisa berdasarkan kaidah dalam software statistika AMOS seri 22. Besaran ukuran regresi pola menjadi dasar dalam kajian ini seperti dalam tabel 5 .: 
Tabel 5. Besaran Ukuran Regresi

\begin{tabular}{|c|c|c|c|c|c|c|c|}
\hline & & & Estimasi & S.E. & C.R. & $\mathrm{P}$ & Predikat \\
\hline Y & $<---$ & Fleksibilitas & 0,481 & 0,133 & 3,610 & $\star \star \star *$ & Buruk \\
\hline Y & $<---$ & Daya ledak & 0,041 & 0,004 & 1,587 & *** & Buruk \\
\hline Y & $<---$ & Kecepatan & 0,014 & 0,002 & 5,926 & *** & Kuat \\
\hline Y & $<---$ & Kelincahan & 0,023 & 0,003 & 3,678 & 0,211 & Kuat \\
\hline Y & $<---$ & Daya tahan & 0,593 & 0,538 & 1,102 & 0,271 & Buruk \\
\hline Y & $<---$ & Koordinasi & 0,150 & 0,105 & 1,439 & 0,150 & Buruk \\
\hline Y & $<---$ & Psikologis & 0,564 & 0,213 & 2,345 & 0,134 & Sangat Buruk \\
\hline Y & $<---$ & Kekuatan & $-0,356$ & 0,262 & $-1,358$ & 0,174 & Sangat buruk \\
\hline Y & $<---$ & Antropometri & 0,011 & 0,307 & 0,035 & 0,972 & Buruk \\
\hline
\end{tabular}

Berdasarkan data Tabel 5. diperoleh gambaran bahwa fleksibilitas, daya ledak, daya tahan, koordinasi, dan antropometri menunjukkan nilai yang signifikan akan tetapi memiliki hubungan yang tidak dominan. Namun, untuk faktor kecepatan dan kelincahan menunjukkan hasil yang signifikan dan sekaligus memiliki hubungan yang paling dominan. Sedangkan, psikologis dan kekuatan menunjukkan hubungan yang tidak signifikan sama sekali.

\section{Impak Analisis Faktor}

Hasil analisis faktor pengaruh psikologis, antropometri, leg muscle strength, lung vital capcity maximal, coordination, dan flexibility yang dihubungkan dengan keterampilan teknik permainan sepakbola dapat dijelaskan pada Tabel 6. di bawah ini:

Tabel 6. Impak Faktor Analisis

\begin{tabular}{clllll}
\hline No. & Variabel & $\begin{array}{l}\text { Estimasi } \\
\text { (Nilai Korelasi) }\end{array}$ & $\mathrm{P}$ & Signifikansi & $\begin{array}{l}\text { Kategori } \\
\text { Hubungan }\end{array}$ \\
\hline 1 & Fleksibilitas & 0,279 & ${ }^{* * *}$ & Signifikan & Lemah \\
2 & Daya ledak & 0,267 & $* * *$ & Signifikan & Lemah \\
3 & Kecepatan & 0,762 & $* * *$ & Signifikan & Kuat \\
4 & Kelincahan & 0,568 & $* * *$ & Signifikan & Kuat \\
5 & Daya tahan & 0,142 & 0,271 & Tidak Signifikan & Lemah \\
6 & Koordinasi & 0,126 & 0,150 Tidak Signifikan & Lemah \\
7 & Psikologis & $-0,106$ & 0,168 Tidak Signifikan & Sangat lemah \\
8 & Kekuatan & $-0,108$ & 0,174 & Tidak Signifikan & Sangat lemah \\
9 & Antropometri & 0,004 & 0,972 Tidak Signifikan & Lemah \\
\hline
\end{tabular}

Tabel 6 di atas merupakan tingkat pengaruh hubungan antara $X$ dengan $Y$ dan dapat dipaparkan seperti di bawah ini:
a. Pengaruh antropometri terhadap keterampilan teknik sebesar 0,004.
b. Pengaruhan kekuatan terhadap keterampilan teknik sebesar -0,108.
c. Pengaruh fleksibilitas terhadap keterampilan teknik sebesar 0,279 . 
d. Pengaruh kecepatan terhadap keterampilan teknik sebesar 0,762.

e. Pengaruh daya tahan terhadap keterampilan teknik sebesar 0,142.

f. Pengaruh koordinasi terhadap keterampilan teknik sebesar 0,126.

g. Pengaruh daya ledak terhadap keterampilan teknik sebesar 0,267.

h. Pengaruh kelincahan terhadap keterampilan teknik sebesar 0,568.

i. Pengaruh faktor psikologis terhadap keterampilan teknik sebesar 0,106 .

\section{PEMBAHASAN}

Hasil dari penelitian ini menunjukkan bahwa faktor dominan penentu keterampilan sepakbola yaitu kecepatan dan kelincahan dengan kadar hubungan yang kuat serta sangat signifikan. Kemudian, faktor fleksibilitas, daya ledak, daya tahan, koordinasi, dan antropometri memberikan hubungan signifikan namun dengan kadar yang tidak kuat. Sedangkan, faktor psikologis dan kekuatan memiliki hubungan yang sangat lemah dan tidak signifikan dalam menunjang keterampilan atlet sepakbola Propinsi Papua.

Tujuan yang ingin dicapai dalam penelitian ini yakni menganalisis, mengkaji dan mendeskripsikan faktor multivariabel hubungan positif yang signifikan antara anatomis tubuh, kemampuan biomotor, psikologis serta dampaknya terhadap hasil keterampilan teknik olahraga permainan tim sepakbola putra PON Propinsi Papua. Selanjutnya, berdasarkan latar belakang permasalahan dan hasil penelitian ini dapat dikaji secara lebih spesifik dan mendalam seperti uraian sebagai berikut:

Proposisi tubuh yang proporsional berguna untuk untuk menunjang keterampilan teknik sepakbola pada atlet putra tim PON Propinsi Papua. Sebagaimana hasil dari significance test faktor antropometri menunjukkan hasil yang lemah, hal ini didasarkan kepada skor peluang sebesar 0,004 yang bermakna bahwa faktor antropometri dengan keterampilan sepakbola memiliki hubungan namun tidak signifikan. Hasil penelitian ini berbanding terbalik dengan temuan penelitian Fakhrullah (2017) menunjukkan bahwa: “...antropometri berhubungan dengan keterampilan teknik sepakbola". Penelitian ini memberikan gambaran kepada pelatih 
sepakbola bahwa tidak semua kondisi dan situasi dapat dipersamakan, utamanya adalah keadaan postur tubuh atlet. Terdapat variabel lain yang turut memberikan peran, yakni kondisi demografi dan faktor pola adaptasi asupan gizi.

Kekuatan merupakan kemampuan otot ketika digunakan untuk menerima beban sewaktu melakukan aktivitas fisik. Sebagaimana hasil dari significance test menunjukkan bahwa faktor kekuatan dalam keterampilan atlet sepakbola Propinsi Papua sebesar $-0,108$ yang berarti tidak signifikan dan memiliki kadar yang sangat lemah. Hasil penelitian ini relevan dengan penelitian Rudiansyah, Atiq, \& Yunitaningrum (2014), unsur kekuatan saja tidak cukup untuk meningkatkan prestasi sepakbola. Unsur kekuatan dalam program latihan sepakbola Propinsi Papua menjadi unsur pelengkap untuk meningkatkan atau memaksimalkan kekuatan atlet dalam mendapatkan dengan kondisi fisik yang prima. Hal ini tidak menjadikan kekuatan kemudian tidak penting, namun lebih kepada proporsi latihan dijalankan untuk meningkatkan keterampilan atlet oleh pelatih di lapangan.

Fleksbilitas dalam penelitian ini adalah kemampuan tubuh atlet sepakbola untuk melakukan gerakan melalui ruang gerak sendi secara maksimal. Sebagaimana hasil dari significance test menunjukkan bahwa faktor fleksibilitas dalam keterampilan sepakbola sebesar 0,279 hal ini berarti signifikan namun memiliki hubungan yang lemah. Penelitian ini memiliki persamaan dengan penelitian Pratama, Sugiyanto, \& Kristiyanto (2018), fleksibilitas berkontribusi positif terhadap kemampuan teknik atlet sepakbola. Hal ini menjadi cerminan bahwa, fleksibilitas otot perut memiliki peran sebagai pengatur stabilitas gerakan tubuh atlet. Setiap kemampuan fleksbilitas pada ruang gerak sendi atlet sepakbola Propinsi Papua tidak sama, sangat bergantung struktur anatominya. Atlet yang memiliki fleksibilitas yang baik sangat memudahkan dalam menjalankan program latihan dan pertandingan serta mengurangi resiko cedera atau kerusakan jaringan otot. Fleksibilitas tubuh seorang atlet dipengaruhi oleh faktor 
umur, jenis kelamin, tipe sendi, bentuk latihan fisik dan proporsi lemak tubuh.

Kecepatan merupakan kemampuan tubuh yang menghasilkan gerakan bersifat lokomotor dalam tempo waktu yang singkat. Sebagaimana hasil dari significance test sebesar 0,762 yang berarti signifikan, hal ini menunjukkan jika faktor kecepatan dalam keterampilan sepakbola memiliki hubungan yang kuat. Kecepatan merupakan faktor tertinggi dalam penunjang keterampilan atlet sepakbola Propinsi Papua. Penelitian ini memiliki relevansi dengan penelitian Kurniawan, Nurrochmah, \& Paulina (2016) kecepatan lari memberikan kontribusi signifikan dalam permainan sepakbola. Bagi seorang atlet sepakbola Propinsi Papua, kapasitas vital paru dalam pengambilan oksigen maksimal serta efektiftas otot dan gerakan persendian memberikan dorongan efisien terhadap performa seorang pemain sepakbola dalam mengontrol permainan di lapangan. Dalam sepakbola kecepatan merupakan faktor yang sangat penting, seorang pemain yang memiliki kecepatan yang baik akan memiliki efektifitas tenaga, namun tidak semua posisi pemain sepakbola mengharuskannya. Meskipun beberapa posisi tetap mengharuskan pemain untuk memiliki kecepatan yang baik seperti bek sayap, penyerang sayap, dan striker. Berbeda dengan sprinter, pemain sepakbola tidak akan berlari sampai jarak $100 \mathrm{~m}$. Jarak sprint terjauh yang dilakukan pemain sepakbola saat pertandingan hanya berkisar antara 10 atau 20 m saja. Oleh karenanya, akselerasi menjadi hal yang paling penting bagi kecepatan pemain sepakbola. Hal ini memungkinkan pemain untuk dapat mencapai kecepatan maksimal dalam waktu singkat.

Daya tahan dalam penelitian ini berhubungan dengan kemampuan atlet sepakbola Propinsi Papua dalam mempergunakan ototnya untuk berkontraksi secara kontinyu dalam waktu yang relatif lama untuk beban tertentu. Sebagaimana hasil dari significance test adalah sebesar 0,142 hal ini berarti hubungan daya tahan dalam keterampilan atlet sepakbola Propinsi Papua adalah lemah dengan kadar yang tidak signifikan. 
Penelitian ini hampir serupa namun memiliki perbedaan dengan riset dari Syahda, Damayanti, \& Imanudin (2016) daya tahan memiliki hubungan terhadap keterampilan teknik permainan sepakbola, namun hubungan ini juga terbilang sangat lemah karena hanya sebesar $22,7 \%$. Daya tahan dalam permainan sepakbola memberikan dorongan terhadap performa tim atau seorang pemain, akan tetapi terdapat faktor-faktor lainnya yang lebih dominan dalam permainan sepakbola. Daya tahan terbagi menjadi dua unsur yaitu: aerobik dan anaaerobik, dalam permainan sepakbola daya tahan anaerobik merupakan proses pemenuhan kebutuhan tenaga seorang pemain memafaatkan glikogen agar menjadi sumber tenaga tanpa bantuan oksigen dari luar. Oleh sebab itu, daya tahan anaerobik tidak seperti daya tahan aerobik, dimana proses pemenuhan kebutuhan energinya tidak memerlukan oksigen dari luar. Daya tahan anaerobik berkorelasi dengan sebagai kecepatan maksimal dalam kerja yang dilakukan menggunakan sumber energinya.

Koordinasi dalam hal ini berkaitan tentang kemampuan atlet sepakbola dalam mengintegrasi gerakan yang multi dinamis dan berbeda kedalam bentuk gerakan tunggal secara tepat. Sebagaimana hasil dari significance test adalah sebesar 0,126 yang berarti bahwa hubungan koordinasi dalam keterampilan atlet sepakbola Papua adalah tidak signifikan dengan kadar yang lemah. Penelitian ini bertolak belakang dengan penelitian Sakti (2017) koordinasi memiliki hubungan signifikan terhadap kemampuan menggiring bola. Hal ini membuktikan bahwa tidak semua sampel dan hasil penelitian dapat digeneralisir, terdapat beragam faktor dan variabel yang memberikan pengaruh. Umumnya, seorang pemain cenderung fokus terhadap bola yang ada dikakinya dan mengabaikan bagaimana posisi pemain lawan dan teman di sekitarnya, oleh karenanya resiko kehilangan bola sangat besar. Pemain tidak dapat menggabungkan seluruh komponen fisik dalam kemampuan mengendalikan bola, koordinasi yang baik akan terlihat apabila seorang pemain mampu melakukan gerak keterampilan dengan cepat dan mudah. 
Daya ledak dalam penelitian ini berhubungan dengan kemampuan atlet sepakbola Propinsi Papua dalam menggunakan energi otot besar secara maksimum untuk dikerahkan pada periode waktu pendek. Sebagaimana hasil dari significance test adalah sebesar 0,267 yang berarti bahwa hubungan koordinasi dalam keterampilan atlet sepakbola Papua adalah signifikan dengan namun kadar yang lemah. Hasil penelitian ini sejalan dengan penelitian Yusviandi, Adurrahman, \& Ifwandi (2016) kekuatan otot tungkai dan keseimbangan memiliki korelasi yang signifikan terhadap performa tendangan sepakbola. Bagi seorang atlet sepakbola Propinsi Papua, daya ledak otot tungkai memberikan kontribusi terhadap permainan karena tendangan dan akurasi terjadinya umpan, dan tendangan memerlukan adanya daya ledak otot tungkai, sehingga hal ini menjadi sangat penting dalam olahraga sepakbola. Maka dari itu, daya ledak otot tungkai dalam sepakbola menjadi penopang dalam permaian. Tungkai yang dengan daya dorong yang kuat berpengaruh besar dalam tendangan jauh.

Kelincahan merupakan kemampuan seorang atlet dalam melakukan rotasi gerak dari satu posisi ke posisi yang lain dalam area tertentu. Sebagaimana hasil dari significance test adalah sebesar 0,568 yang berarti bahwa hubungan kelincahan dalam keterampilan atlet sepakbola Papua adalah signifikan dengan kadar yang kuat. Penelitian ini memiliki relevansi dengan penelitian (Widyaningsih, Handayani, \& Hidayah, 2016) variabel kelincahan memberikan kontribusi sebesar 26,8\% terhadap keterampilan atlet. Kelincahan dalam permainan tim sepakbola Propinsi Papua berhubungan dengan keadaan pada saat seorang pemain menggiring dan membawa bola yang dikontrol pada saat berlari dalam penguasaannya. Oleh karenanya, dapat dikatakan bahwa kelincahan berdampak pada kesanggupan seorang pemain dalam mengubah arah dan posisi tubuh dengan cepat tanpa ada gangguan dalam keseimbangan atau kesadaran akan posisi tubuhnya.

Faktor psikologis dalam hal ini interpersonal dalam tim sepakbola Papua merupakan suatu cara bagi atlet untuk mengumpulkan dan 
mengelompokkan kekonsistenan reaksi seorang individu terhadap situasi yang sedang terjadi. Sebagaimana dirunut dari hasil significance test adalah sebesar - 0,106 yang berarti bahwa hubungan faktor psikologis dalam keterampilan atlet sepakbola Papua adalah tidak signifikan dengan kadar yang sangat lemah. Penelitian ini sangat relevan dengan penelitian Nazori, Juriana, \& Dewanti (2017) mental dan kepribadian atlet tidak berbanding lurus terhadap keterampilan yang dimiliki. Hasil riset ini menunjukkan bahwa mental dan kepribadian dapat dipengaruhi banyak faktor ketika seorang pemain sepakbola bermain di lapangan, dapat disebabkan tekanan psikologis untuk menang maupun keputusan wasit dan pendukung kesebelasan yang bertanding. Terdapat beberapa dimensi dari karakteristik pribadi seorang pemain sepakbola, yakni: (1) umur dan tahap siklus hidup, (2) pekerjaan, (3) situasi ekonomi, (4) gaya hidup, dan (5) keperibadian dan konsep diri. Faktor psikologis atlet sepakbola tidak semata merujuk pada bagaimana perasaan, pikiran dan tindakan.

Sebagaimana diketahui dalam teori latihan terdapat 4 aspek latihan yaitu: latihan fisik, latihan teknik, latihan taktik, dan latihan mental. Faktor fisik dan psikologis dominan yang mendukung keterampilan dapat semakin baik apabila diberikan porsi latihan yang sesuai dengan psosisi permainan. Latihan yang spesifik memungkinkan atlet untuk semakin beradaptasi dengan prinsip spesialisasi mereka. Akan tetapi, dalam melatih setiap komponen sudah barang tentu diperlukan latihan yang efektif, efisien, dan berkualitas seperti: volume latihan, intensitas latihan, istirahat latihan (interval latihan), densitas latihan (frekuensi/kekerapan). Adapun aspek fisik yang sangat menunjang bagi penguasaan teknik dasar dalam sepakbola merupkan perpaduan keberhasilan metode latihan yang efektif, efisien dan berkualitas dengan talenta bakat yang dimiliki atlet. Meskipun ada beberapa aspek yang dominan, bukan berarti faktor-faktor yang lain dianggap tidak penting, tetap saja harus dilatih secara keseluruhan terutama bila sudah dibuatkan periodisasi latihan pada tahap persiapan umum yang dilakukan sebaik-baiknya. 


\section{KESIMPULAN DAN SARAN}

\section{Kesimpulan}

Kesimpulan dari penelitian ini yaitu faktor kemampuan fisik dalam keterampilan atlet sepakbola Propinsi Papua yang hubungan signifikan, namun dalam kadar yang lemah adalah fleksibilitas, daya ledak, daya tahan, koordinasi, dan antropometri. Kemudian, yang menghasilkan hubungan yang signifikan dalam kadar yang kuat adalah kecepatan dan kelincahan. Sedangkan kekuatan dan psikologis merupakan faktor yang memiliki hubungan yang tidak signifikan dengan kadar yang sangat lemah.

\section{Saran}

Rekomendasi berkaitan hasil riset ini sangat perlu diberikan mengingat pelatih/atlet, peneliti, dan pemangku kepentingan untuk dapat menggunakan hasil penelitian ini sebagai rujukan, karena memberikan manfaat dalam pembinaan olahraga prestasi.

\section{REFERENSI}

Amerieska, S., \& Nurhidayah. (2014). Analisis Faktor-Faktor yang Mempengaruhi Kinerja Kemitraan Bisnis PT PLN. Jurnal Manajemen dan Akuntansi, 3(2), 1-14.

Asier, L., \& Javier, M. (2018). Physical Fitness Performance of Young Professional Soccer Players Does Not Change During Several Training Seasons in a Spanish Elite Reserve Team: Club Study, 1996-2013. Journal of Strength and Conditioning Research, 32(9), 2577-2583.

Dewi, A., \& Prihatanta, H. (2015). Hubungan Berat Badan dan Tinggi Badan dengan Kelincahan Pemain Futsal Putri UNY. Medikora, 16(2), 1-11.

Elemiri, A., \& Aly, A. (2014). Mental Toughness and its Relationship to The Achievement Level of the Weightlifters in Egypt. Turkish Journal of Sport and Exercise, 16(2), 63-69.

Etikan, I., Musa, S., \& Alkassim. (2016). Comparison of Convenience Sampling and Purposive Sampling. American Journal of Theoretical and Applied Statistics, 5(1), 1-4.

Fakhrullah. (2017). Analisis Antroprometrik Atlet Sepakbola Universitas Serambi Mekkah Banda Aceh. Jurnal Penjaskesrek, 4(2), 151-162.

Hatzigeorgiadis, A., Galanis, E., Zourbanos, N., \& Theodorakis, Y. (2014). Self-talk and Competitive Sport Performance. Journal of Applied Sport Psychology, 26(1), 82-95. 
Hidayat, A., Imanudin, I., \& Ugelta, S. (2019). Analisa Kebutuhan Latihan Fisik Pemain Sepakbola Dalam Kompetisi AFF U-19 (Studi Analisis Terhadap Pemain Gelandang Timnas Indonesia U-19). Jurnal Terapan IImu Keolahragaan, 4(1), 25-28.

Indrayana, B., \& Sukendro. (2019). Hubungan Standing Broad Jump dan Lari Sprint 20 Meter Terhadap Hasil Kemampuan Lompat Jauh pada Siswa Kelas XI SMA Xaverius II Kota Jambi. Jurnal Prestasi, 3(5), , $19-24$.

Kurniawan, D., Nurrochmah , S., \& Paulina, H. (2016). Hubungan Antara Kecepatan Lari dengan Kemampuan Menggiring Bola Sepak pada Siswa Usia 13-14 Tahun SSB UNIBRAW 82 Malang. Jurnal Pendidikan Jasmani, 26(2), 381-397.

Kurniawan, E., Kesoema, T., \& Hendrianingtyas. (2019). Pengaruh Latihan Fleksi dan Ekstensi Lumbal Terhadap Fleksibilitas Lumbal pada Dewasa Muda. Jurnal Kedokteran Diponegoro, 8(1), 161-170.

Kusuma, I. D. (2018). Upaya Meningkatkan Hasil Belajar Dribble Sepak Bola Melalui Model Pembelajaran Numbered Head Together (NHT) dan Media Audio Visual. Jurnal Sportif, 4(1), 73-86.

Meliala, E. K., \& Fithroni, H. (2018). Analisis Kondisi Fisik Atlet Putra Floorball Universitas Negeri Surabaya. Jurnal Kesehatan Olahraga, 3(5), 19-24.

Mitrotasios, M., Souglis, A., Gioldasis, A., Kesaris, N., \& Kampouris, T. (2018). A New Test for the Assessment of Agility and Dribbling Skill of Soccer Playe rs Aged 14-15 Years Old. International Journal of Science Culture and Sport, 6(4), 425-433.

Morgan, H., \& Batlle, I. (2019). "It's Borderline Hypocrisy": Recruitment Practices in Youth Sport-Based Interventions. Journal of Sport for Development, 7 (13), 1-14.

Nazori, Juriana, \& Dewanti, R. (2017). Penyusunan Norma Mental Skills Pemain Sepakbola Usia 14 Tahun (Konsentrasi, Kemampuan Visualisai dan Imajeri, Kontrol Perilaku). Jurnal Ilmiah Sport Coaching and Education, 1(2), 15-25.

Orçan, F. (2018). Exploratory and Confirmatory Factor Analysis: Which One to Use First? Journal of Measurement and Evaluation in Education and Psychology, 9(4), 414-421.

Pratama, A., Sugiyanto, \& Kristiyanto, A. (2018). Sumbangan Koordinasi Mata-Kaki, Kelincahan, Keseimbangan Dinamis dan Fleksibilitas Togok Terhadap Kemampuan Menggiring Bola pada Permainan Sepak Bola (Studi Korelasional pada Pemain Sepak Bola Mahasiswa. Jurnal Sportif, 4(1), 15-27.

Rachman, G., \& Nasution, J. (2017). Survei Tingkat Kebugaran Jasmani Siswa Cerdas Istimewa Angkatan Tahun 2014 dan Angkatan Tahun 
2015 SMA Negeri 1 Krian. Jurnal Pendidikan Olahraga dan Kesehatan, 5(1),, 44-48.

Rudiansyah, Atiq, A., \& Yunitaningrum, W. (2014). Kekuatan Otot Tungkai dan Kelincahan Terhadap Kecepatan Dribbling Sepakbola di SMAN 1 Tebas". Jurnal Pendidikan dan Pembelajaran, Vol. 3 (6), 1-12.

Sakti, B. P. (2017). Hubungan Koordinasi Mata-Kaki dan Kelincahan dengan Keterampilan Menggiring Bola dalam Permainan Sepakbola pada Siswa Ekstrakurikuler SMA Negeri 2 Lubuklinggau. Biomatika, 3(2), 246-3961.

Saptono, A. (2017). Development Instruments Through Confirmatory Factor Analysis (CFA) in Appropriate Intensity Assessment. Dinamika Pendidikan, 12(1), 14-20.

Syahda, I., Damayanti, I., \& Imanudin, I. (2016). Hubungan Kapasitas Vital Paru-Paru Dengan Daya Tahan Cardiorespiratory pada Cabang Olahraga Sepakbola. Jurnal Terapan IImu Keolahragaan, 1(1), 2428.

Trecroci, A., Milanović, Z., \& Frontini, M. (2018). Physical Performance Comparison Between Under 15 Elite and Sub-Elite Soccer Players. Journal of Human Kinetics, 61(1), 1-8.

Widodo, A. (2018). Pengembangan Model Permainan Target untuk Meningkatkan Keterampilan Shooting dalam Permainan Sepakbola. Jurnal Sportif, 4(2), 248-263.

Widyaningsih, W., Handayani, O., \& Hidayah, T. (2016). The Relationship between Personality of Single and Double Athletes of Badminton Toward Achievement Level in PB. Djarum. Journal of Physical Education and Sports, 7(1), 1-6.

Yusviandi, A. \& Ifwandi. (2016). Hubungan Powerotot Tungkai dengan Kemampuan Tendangan (Shooting) dalam Sepakbola Pada Klub Himadirga Program Studi Penjaskesrek FKIP Unsyiah Tahun 2015. Jurnal IImiah Mahasiswa Penjaskesrek FKIP Unsyiah, 2(3), 31-40. 